\title{
Baclofen Inhibits Postsynaptic Voltage-dependent Calcium Currents of Supraoptic Nucleus Neurons Isolated from Young Rats
}

\author{
Jun Noguchi and Hiroshi Yamashita \\ Department of Physiology, School of Medicine, University of Occupational and Environmental Health, Kitakyushu 807-8555, \\ Japan
}

(Received 24 September 1999; and accepted 30 September 1999)

\begin{abstract}
Direct postsynaptic effects of $\mathrm{GABA}_{\mathrm{B}}$ receptor agonist, baclofen, on voltage-dependent $\mathrm{Ca}^{2+}$ currents (VDCC) were examined by whole-cell-patch clamp recording in magnocellular neurons of the supraoptic nucleus (SON) isolated from young male Wistar rat (5-8 weeks). Baclofen $(10 \mu \mathrm{M})$ reversibly inhibited VDCC elicited by depolarizing voltage steps from a holding potential of $-80 \mathrm{mV}$. The baclofen-induced inhibition of VDCC was reversed by depolarizing up to $+150 \mathrm{mV}$ with $100 \mathrm{~ms}$ prepulse, but remained unaffected by intracellular application of pre-activated pertussis toxin (PTX; $1 \mu \mathrm{g} / \mathrm{mL}$ ). Gene expression of $\alpha$-subunits of the PTX-sensitive G proteins ( $\mathrm{Gi}$ and $\mathrm{Go}$ ) was not detected by in situ hybridization histochemistry in the SON of young rats, while that of the PTX-insensitive (GS) $\alpha$-subunit gene was abundant. These results are compatible with a view that, in SON magnocellular neurons isolated from young rats, the inhibition of VDCC activated by $\mathrm{GABA}_{\mathrm{B}}$ receptors may be mediated by a PTX-insensitive G protein.
\end{abstract}

Gamma $(\gamma)$-aminobutyric acid (GABA) is well known as a major inhibitory neurotransmitter in the central nervous system (CNS) (24). GABA receptors are pharmacologically classified as either ionotropic $\mathrm{GABA}_{\mathrm{A}}$ and $\mathrm{GABA} \mathrm{C}_{\mathrm{C}}$ receptors, or metabotropic $\mathrm{GABA}_{\mathrm{B}}$ receptors (2). $\mathrm{GABA}_{\mathrm{A}}$ and $\mathrm{GABA}_{C}$ receptors are ligand-gated $\mathrm{Cl}^{-}$channels that mediate fast synaptic currents $(1,21,30)$, whereas $\mathrm{GABA}_{B}$ receptors are $\mathrm{G}$ protein-coupled receptors (19) that mediate slow inhibitory synaptic currents (31). $\mathrm{GABA}_{\mathrm{B}}$ receptors mediate inhibition of release of neurotransmitters via presynaptic or postsynaptic mechanisms, including the closure of $\mathrm{Ca}^{2+}$ channels, the opening of $\mathrm{K}^{+}$channels and modulation of adenylate cyclases $(7,23)$.

Magnocellular neurosecretory cells in the

Correspondence to: Dr Hiroshi Yamashita at above address. Tel: +81-93-691-7420, Fax: +81-93-6921711,E-mail: yama@med.uoeh-u.ac.jp hypothalamic supraoptic nucleus (SON) and the paraventricular nucleus (PVN) are known to produce arginine vasopressin (AVP) and oxytocin (OXT), and to release these hormones from their axon terninations in the neurohypophysis into the systemic circulation. The neuronal activities of magnocellular neurosecretory cells in the SON and the PVN have been well linked to secretions of AVP and OXT into the circulation. The neuronal activities of these neurons are regulated by humoral and neural inputs to the SON and the PVN. The major neural signals to the SON are known to be excitatory glutamatergic inputs and inhibitory GABAergic inputs (11, $20,25,28,32)$. Recent studies have demonstrated that inhibitory actions of GABA in the SON are mediated by presynaptic $\mathrm{GABA}_{\mathrm{B}}$ receptors (16, 22) and by postsynaptic $\mathrm{GABA}_{\mathrm{A}}$ (13) and $\mathrm{GABA}_{\mathrm{B}}$ receptors $(9,11)$.

Harayama et al. demonstrated that $\mathrm{GABA}_{\mathrm{B}}$ receptors exist in the postsynaptic membranes of 
magnocellular neurosecretory cells in the SON of infant rats (1-3 weeks) where they mediate selective inhibitory actions on voltage-dependent $\mathrm{Ca}^{2+}$ currents (VDCC) via pertussis toxin (PTX)sensitive $G$ proteins (9). However, in the SON magnocellular neurons in young rats, detailed inhibitory mechanisms followed by the activation of $\mathrm{GABA}_{\mathrm{B}}$ receptors are not yet established, although the inhibitory effects of GABA on the activity of SON neurons in young rats has been demonstrated by several studies $(11,13,16)$.

Although $\mathrm{GABA}_{\mathrm{B}}$ receptors are generally thought to be coupled to PTX-sensitive G proteins in the CNS (29), PTX-insensitive G proteins have also been reported to be partially responsible for $\mathrm{GABA}_{\mathrm{B}}$ receptor-mediated inhibition of VDCC in cultured rat suprachiasmatic nucleus neurons (4). Previous studies have demonstrated that the expression levels of $G$ proteins in the rat CNS changed during postnatal development (21) and ADP-ribosylation by PTX increased for up to 1 week postnatal and then decreased (3). Thus, there is a possibility that the PTX-sensitivity of $\mathrm{GABA}_{\mathrm{B}}$ receptors may be different in infant and young rat SON neurons.

In the present study, the actions of the $\mathrm{GABA}_{B}$ receptor agonist baclofen on VDCC in SON magnocellular neurons isolated from young male Wistar rats (5-8 weeks) was examined by using the whole-cell-patch clamp technique. In addition, the effects of a large depolarizing conditioning pulse was used to examine whether the action of baclofen on these VDCC was mediated by the $\mathrm{G}$ protein-coupled receptor because $\mathrm{G}$ protein $\beta \gamma$ subunit-mediated inhibition is known to be reversed by such large depolarization prepulses (10, 12). The effects of PTX on the baclofen-induced inhibition of VDCC in these SON magnocellular neurons was also examined. To confirm the effectiveness of these experimental methods, we also investigated voltage-dependent $\mathrm{Ba}^{2+}$ currents in melanotrophs isolated from the neurointermediate lobe of pituitary glands of young rats. Finally, the expression levels of the PTX-sensitive $\mathrm{G}$ protein ( $\mathrm{Gi}$ and $\mathrm{Go}$ ) $\alpha$-subunit genes in the SON of young rats were examined by in situ hybridization histochemistry.

\section{MATERIALS AND METHODS}

\section{Animals and Tissue Preparations}

Young male Wistar rats at 5-8 weeks of age (125$250 \mathrm{~g}$ ) were used. Rats were first stunned by a blow on the neck and then rapidly decapitated. The brain and pituitary glands were quickly removed and cooled in a bathing medium at $4^{\circ} \mathrm{C}$ for approximately $1 \mathrm{~min}$. The bathing medium contained $(\mathrm{mM}): \mathrm{NaCl}, 124 ; \mathrm{KCl}, 5 ; \mathrm{MgSO}_{4}$, 1.3; $\mathrm{KH}_{2} \mathrm{PO}_{4}, 1.24 ; \mathrm{CaCl}_{2}, 2 ; \mathrm{NaHCO}_{3}, 25.9$ and glucose, 10 . Bathing medium was equilibrated with $95 \% \mathrm{O}_{2}-5 \% \mathrm{CO}_{2}$. The osmolality, as determined with a One-Ten osmometer (Fiske Associates, Norwood, USA), was 300-310mosmol $/ \mathrm{kg}$. This bathing solution was continuously oxygenated with a mixture of $95 \% \mathrm{O}_{2}-5 \% \mathrm{CO}_{2}$. A block containing the hypothalamus was cut from the brain and was glued to the stage of the vibratometype slicer (DSK-2,000; DOSAKA EM Co., LTD, Kyoto, Japan), and immersed in $4^{\circ} \mathrm{C}$ bathing solution. Coronal slices of $300 \mu \mathrm{m}$ in thickness containing the SON were cut from this brain block and were carefully trimmed around the SON with a circular micro punch (inner diameter (i.d.) $1.0 \mathrm{~mm}$ ). For isolation of individual SON neurons, these trimmed slices were pre-incubated in the bathing medium at room temperature (23$25^{\circ} \mathrm{C}$ ) for at least $1 \mathrm{~h}$ and then transferred to a digestion solution. For the melanotroph experiments, the pituitary neurointermediate lobe was carefully isolated from the anterior lobe and transferred to the standard perfusion medium (2[4-(2-hydroxyethyl)-1-piperazinyl] ethanesulfonic acid (HEPES)-buffered solution, HBS, described below) and then pre-incubated in this oxgenated HBS medium at room temperature $\left(23-25^{\circ} \mathrm{C}\right)$ for at least $\mathrm{l} \mathrm{h}$, after which they were transferred to the digestion solution.

\section{Isolation of SON magnocellular Neurons and Melanotrophs}

After incubation at room temperature for at least $1 \mathrm{~h}$, the trimmed slices were incubated in a digestion solution, which was the same as the bathing medium but also contained trypsin (0.1 $\mathrm{mg} / \mathrm{mL}$, Sigma type XI), for $90 \mathrm{~min}$ at $28^{\circ} \mathrm{C}$. They were then transferred into bathing medium which contained trypsin inhibitor $(1 \mathrm{mg} / \mathrm{mL}$, Nacalai Tesque) for $10 \mathrm{~min}$ at $28^{\circ} \mathrm{C}$. These slices were then removed back to the bathing medium and kept for less than $8 \mathrm{~h}$ until use. Individual trimmed slices were transferred to a culture dish and then mechanically isolated by triturating with firepolished glass pipettes (tip i.d. ranging from 250 to $650 \mu \mathrm{m})$ in the standard recording solution continuously oxygenated with humidified 
$100 \% \mathrm{O}_{2}$. The isolated neurons were left for at least 5 min to enable them to adhere to the bottom of the culture dish.

For melanotroph experiments, the lobes were incubated in HBS, containing $0.2 \%$ trypsin (Sigma type III) and $0.1 \%$ bovine serum albumin (BSA), at $37^{\circ} \mathrm{C}$ for $20 \mathrm{~min}$ and continuously shaken $(100$ cycles $/ \mathrm{min})$. The lobes were then incubated in $\mathrm{Ca}^{2+}$-free HBS containing $0.1 \%$ collagenase (Sigma type I) and $0.1 \%$ BSA for 15 min and triturated with glass pipettes. Isolated cells thus obtained were washed twice with enzyme-free HBS and maintained at room temperature $\left(23-25^{\circ} \mathrm{C}\right)$ for at least $4 \mathrm{~h}$, until used.

\section{Solutions}

Standard perfusion medium (HEPES-buffered solution, $\mathrm{HBS}$ ) contained (mM): $\mathrm{NaCl}, 140 ; \mathrm{KCl}$, 5; $\mathrm{MgCl}_{2}, 1 ; \mathrm{CaCl}_{2}, 2$; HEPES, 10 and glucose, 11.1 The osmolality was $300-310 \mathrm{mosmol} / \mathrm{kg}$ and pH 7.4 (adjusted with $\mathrm{NaOH}$ ). HBS was continuously oxygenated with $100 \% \mathrm{O}_{2}$ throughout the experiments. $\mathrm{Ca}^{2+}$ current recording medium contained $(\mathrm{mM}): \mathrm{NaCl}, 140 ; \mathrm{KCl}, 5 ; \mathrm{CaCl}_{2}, 2$; HEPES, 10: glucose, 11.1 and tetrodotoxin (TTX), 0.001. The osmolality was 300-310 mos$\mathrm{mol} / \mathrm{kg}$ and $\mathrm{pH} 7.4$ (adjusted with $\mathrm{NaOH}$ ). $\mathrm{Ca}^{2+}$ current recording medium was also continuously oxygenated with $100 \% \mathrm{O}_{2}$. For the $\mathrm{Ba}^{2+}$ current recording in melanotroph, the medium was; Choline $\mathrm{Cl}, 140 ; \mathrm{KCl}, 5 ; \mathrm{BaCl}_{2}, 10$; HEPES, 10 and glucose, 11.1. The osmolality was also 300$310 \mathrm{mosmol} / \mathrm{kg}$ and $\mathrm{pH} 7.4$ (adjusted with Tris base). The pipette solution used for $\mathrm{Ca}^{2+}$ or $\mathrm{Ba}^{2+}$ current measurements contained $(\mathrm{mM})$ : tetraethylammonium hydrochloride (TEA-Cl), 100; 4-aminopyridine (4-AP), 5; $\mathrm{MgCl}_{2}, 1 ; \mathrm{CaCl}_{2}, 1$; EGTA, 10; HEPES, 10; Mg-ATP, 2; creatine phosphate di-tris, 20; $\mathrm{Na}_{2}$-GTP, 0.3. The osmolality was $280-290 \mathrm{mosmol} / \mathrm{kg}$ and $\mathrm{pH} 7.2$ (adjusted with Tris base). "Rundown" of $\mathrm{Ca}^{2+}$ currents was effectively reduced by using an ATP-regenerating system.

\section{Whole-cell-patch clamp Recording}

Isolated neurons were perfused with HBS at a flow rate of $1.5 \mathrm{~mL} / \mathrm{min}$. The solution in the dish was kept at a constant volume by a low pressure aspiration system. Magnocellular neurons were identified using an upright microscope (Nikon, Tokyo, Japan). Only neurons, which had the morphological appearance of magnocellular SON neurons: a large soma with diameters $>15 \mu \mathrm{m}$, were used for whole-cell-patch clamp recording. Over $96 \%$ of the neurons selected by the above criteria were thought to be neurosecretory cells (26). Patch-clamp electrodes were made from glass capillaries (GD-1.5, Narishige, Tokyo, Japan) with a horizontal pipette-puller (P-87; Sutter Instrument Co., Novoto, USA). They had a final resistance of between 6 and $8 \mathrm{M} \Omega$ when filled with the electrode solution. All electrophysiological recordings were carried out at room temperature $\left(23-25^{\circ} \mathrm{C}\right)$. Whole-cell, tight-seal $(1-5$ $\mathrm{G} \Omega$ ), recordings were made from microscopically identified SON neurons. Recording of membrane currents was delayed for 5-10 min after membrane rupture, until the currents reached a steady level. However, the effects of PTX on baclofeninduced inhibition of VDCC were examined shortly after membrane rupture, because PTX is known to express its effects within a few minutes (17). Currents were recorded with a patch-clamp amplifier (AxoPatch 200A; Axon Instruments Inc., Foster City, USA), and were digitlized at $10 \mathrm{kHz}$ using pCLAMP software (version 6.0.3; Axon Instruments Inc., Foster city, USA) for subsequent off-line analysis. After making a whole-cell recording, the perfusion medium was switched to the $\mathrm{Ca}^{2+}$ or $\mathrm{Ba}^{2+}$ current recording medium, as described above.

\section{Isolation of $\mathrm{Ca}^{2+}$ or $\mathrm{Ba}^{2+}$ Current}

$\mathrm{Ca}^{2+}$ or $\mathrm{Ba}^{2+}$ currents were pharmacologically isolated using the following combination of drugs in the perfusion medium and pipette solution. For the recording from SON neurons, the sodium current was blocked by $1 \mu \mathrm{M}$ TTX in the perfusion medium and $\mathrm{NaCl}$ was exchanged with to choline chloride for the melanotroph recordings. Potassium currents were blocked by inclusion of $100 \mathrm{mM}$ TEA-Cl and $5 \mathrm{mM} 4-\mathrm{AP}$ in the pipette solution. Leak and capacitative currents were cancelled by off-line subtraction of $\mathrm{Ni}^{+}(100$ $\mu \mathrm{M})$ and $\mathrm{Cd}^{2+}(200 \mu \mathrm{M})$ insensitive currents.

\section{Preparation of the Pipette Solution Containing PTX}

PTX was intracellularly applied using a modified method of Kakehata et al. (17). PTX was preactivated by adding to pipette solution containing dithiothreitol $(5 \mathrm{mM})$ and left for $30 \mathrm{~min}$ at $37^{\circ} \mathrm{C}$. 
It was then diluted in additional pipette solution containing beta-nicotinamide adenine dinucleotide (NAD) $(5 \mathrm{mM})$. The final concentration of PTX was $1 \mu \mathrm{g} / \mathrm{mL}$.

\section{Pharmacological Agents}

Baclofen, serotonin (5-HT), trypsin, NAD and creatine phosphate di-tris were purchased from Sigma (St. Louis, USA), TTX was from Sankyo Co,. Ltd. (Tokyo, Japan), PTX was from Seikagaku Co,. Ltd. (Tokyo, Japan) and all other chemicals were from Nacalai Tesque (Kyoto, Japan).

\section{Analysis}

Data were analyzed using AxoGraph software (version 3.6; Axon Instruments Inc., Foster City, USA). $\mathrm{Ca}^{2+}$ or $\mathrm{Ba}^{2+}$ current recorded between 3 and $8 \mathrm{~ms}$ after depolarizing voltage steps were averaged for further analysis. The magnitude of $\mathrm{Ca}^{2+}$ or $\mathrm{Ba}^{2+}$ current inhibition was expressed as a percentage inhibition of the control currents, which was the averaged currents measured just before application of drugs and after recovering completely from the effects of these drugs.

\section{In situ hybridization histochemistry}

In situ hybridization histochemistry was performed on frozen, $12 \mu \mathrm{m}$-thick, coronal brain sections which were cut by cryostat at $-20^{\circ} \mathrm{C}$, thawed and then mounted onto gelatin/chrome alum-coated slides that were kept at $-80^{\circ} \mathrm{C}$ until needed. The locations of the PVN and SON were determined according to coordinates given by Paxinos and Watson (27). The slides were warmed to room temperature and allowed to dry for $10 \mathrm{~min}$, and then fixed in $4 \%$ formaldehyde in phosphate buffered saline (PBS) for $5 \mathrm{~min}$. They were then washed twice in PBS, and incubated in $0.9 \% \mathrm{NaCl}$ containing $0.25 \%$ acetic anhydride (vol/vol) and $0.1 \mathrm{M}$ triethanolamine at room temperature for $10 \mathrm{~min}$. The sections were then dehydrated using a series of $70 \%(1 \mathrm{~min}), 80 \%$ (1 $\mathrm{min}), 95 \%(2 \mathrm{~min})$ and $100 \%(1 \mathrm{~min})$ ethanol solutions in a stepwise manner and delipidated in $100 \%$ chloroform for $5 \mathrm{~min}$. The slides were then partially rehydrated in first $100 \%(1 \mathrm{~min})$ and then $95 \%(1 \mathrm{~min})$ ethanol and allowed to dry briefly in the open air. Hybridization was performed at $37^{\circ} \mathrm{C}$ overnight in a $45 \mu \mathrm{L}$ buffer solution consisting of $50 \%$ formamide and $4 \times \operatorname{SSC}(1 \times$ $\mathrm{SSC}=150 \mathrm{mM} \mathrm{NaCl}, 15 \mathrm{mM}$ sodium citrate) which also contained $500 \mu \mathrm{g} / \mathrm{mL}$ sheared salmon sperm DNA (Sigma, St. Louis, MO, USA), 250 $\mu \mathrm{g} / \mathrm{mL}$ baker's yeast total RNA (Boehringer Mannheim GmbH, Mannheim, Germany), $1 \times$ Denhardt's solution and $10 \%$ dextran sulfate (500,000 M Wt, Sigma, St. Louis, MO, USA). The hybridization was performed under a Nescofilm (Bando Chemical IMD, Ltd., Osaka, Japan) coverslip. A ${ }^{35} \mathrm{~S} 3$ ' end-labelled deoxyoligonucleotide complementary to transcripts coding for $\mathrm{G}$ proteins $\alpha$-subunits (Gs (probe sequence $=$ 5'-TCC-AGA-GGT-CAG-GAC-ACG-GCAGCG-AAG-CAG-GTC-CTG-GTC-3'), Gi (5'GCC-CGT-GGT-CTT-CAC-ACG-GGT-CCGCAG-CAC-ATC-CTG-CTG-3') and Go (5'GCC-AGT-TGT-TTT-GAC-CCT-GGT-TCGGAG-GAT-GTC-CTG-CTC-3') ) were used. A total of $1 \times 10^{6} \mathrm{cpm} / \mathrm{slide}$ for $\mathrm{Gs}, \mathrm{Gi}$ and $\mathrm{Go}$ $\alpha$-subunits transcripts were used. After hybridization, the sections were washed for $1 \mathrm{~h}$ in four changes of $1 \times \mathrm{SSC}$ at $55^{\circ} \mathrm{C}$ and for a further $1 \mathrm{~h}$ in two changes of $1 \times \mathrm{SSC}$ at room temperature. Hybridized sections of the PVN and SON were apposed using autoradiography film (Hyperfilm, Amersham, Bucks, UK) for 7 days. The resulting images were analyzed by computerized densitometry using an MCID imaging analyzer (Imaging Research Inc., St. Catharine, Ontario, Canada). The mean optical density of autoradiographs was measured by comparing it with simultaneously exposed $\left[{ }^{14} \mathrm{C}\right]$ micro-scale samples (Amersham, Bucks, UK).

\section{Statistical analysis}

All data shown represent the mean \pm SEM. Student's $t$-test or analysis of variance was applied, as appropriate, to determine the statistical significance. $P<0.05$ was regarded as a significant difference.

\section{RESULTS}

\section{Effects of Baclofen on VDCC currents in SON Neurons of Young Rats}

The time course of inhibition of the high threshold $\mathrm{Ca}^{2+}$ currents by baclofen $\left(10^{-5} \mathrm{M}\right)$ was examined by measuring peak currents in response to a voltage command from $-80 \mathrm{mV}$ to -10 or $-20 \mathrm{mV}$ applied at $10 \mathrm{~s}$ intervals. These currents were measured in $25 \mathrm{SON}$ neurons isolated 
from 10 young rats. $\mathrm{Ca}^{2+}$ currents measured between 3 and $8 \mathrm{~ms}\left(\mathrm{I}_{\mathrm{Ca3}-\mathrm{s}}\right)$ after the voltage steps were rapidly reduced when baclofen $\left(10^{-5} \mathrm{M}\right)$ was applied and recovered rapidly upon withdrawal of baclofen. A similar time course was observed when $\mathrm{Ca}^{2+}$ currents were measured between 24 and $34 \mathrm{~ms}\left(\mathrm{I}_{\mathrm{Ca} 24-34}\right)$ after the voltage step, although the magnitude of this inhibition was smaller. Baclofen $\left(10^{-5} \mathrm{M}\right)$ inhibited $\mathrm{Ca}^{2+}$ currents with a clear 'kinetic slowing' of the currents as well as 'steady-state inhibition'. Representative time courses for the inhibition of $\mathrm{Ca}^{2+}$ currents induced by baclofen $\left(10^{-5} \mathrm{M}\right)$ are shown in Fig. $1 \mathrm{~A}$.

Fig. 1B shows typical examples of $\mathrm{Ca}^{2+}$ currents elicited by stepwise depolarizing test potentials from -60 to $+50 \mathrm{mV}$ from a holding potential of $-80 \mathrm{mV}$ and the inhibitory effects of baclofen $\left(10^{-5} \mathrm{M}\right)$ on these currents. Currentvoltage relations of $\mathrm{Ca}^{2+}$ currents were measured before, during and after the application of baclofen $\left(10^{-5} \mathrm{M}\right)$. The inhibitory effects of baclofen on $\mathrm{Ca}^{2+}$ currents were reversible upon washout of baclofen. The averaged $\mathrm{Ca}^{2+}$ currents-voltage relationships $(n=7)$ are shown in Fig. 1C.

The voltage dependency of the inhibition of $\mathrm{Ca}^{2+}$ currents by baclofen $\left(10^{-5} \mathrm{M}\right)$ was calculated from the voltage dependence of the inhibition (Fig. 1D). The maximum inhibition of $\mathrm{Ca}^{2+}$ currents induced by baclofen $(40.7 \pm 1.1 \%$ (mean \pm S.E.M., $\mathrm{n}=7$ )) occurred at $-20 \mathrm{mV}$.

\section{Effects of Prepulse on Baclofen-induced Inhibi- tion of VDCC in the SON Neurons of Young Rats}

Three consecutive $50 \mathrm{~ms}$ stepwise depolarizations $\left(\mathrm{P}_{1}, \mathrm{P}_{2}\right.$ and $\left.\mathrm{P}_{3}\right)$ from $-80 \mathrm{mV}$ to $-20 \mathrm{mV}$ were applied. A prepulse (to $150 \mathrm{mV}$ for $100 \mathrm{~ms}$ ) before $\mathrm{P}_{2}$ potently reversed the baclofen $\left(10^{-5}\right.$ $M)$-induced inhibition of VDCC. The baclofeninduced inhibition of $\mathrm{Ca}^{2+}$ currents in response to the third command pulse $\left(\mathrm{P}_{3}\right)$ recovered to a similar level to that observed in response to the first command $\left(P_{1}\right)$. A representative example of the effects of this prepulse on baclofen-induced inhibition of VDCC is shown in Fig. 2A. These effects by the prepulse in reducing the baclofeninduced inhibition of VDCC was observed in all 11 SON neurons isolated from 4 young rats. This depolarizing prepulse also facilitated (or disinhibited) an early, rapidly inactivating component of the $\mathrm{Ca}^{2+}$ current. This facilitation ratio was $1.26 \pm 0.03$ (mean \pm S.E.M., $\mathrm{n}=11)$. This facilitat- ed current is thought to reflect tonic voltagedependent inhibition of the $\mathrm{Ca}^{2+}$ channels. The facilitation ratio after application of baclofen $\left(10^{-5} \mathrm{M}\right)$ was significantly increased $(P<0.05)$

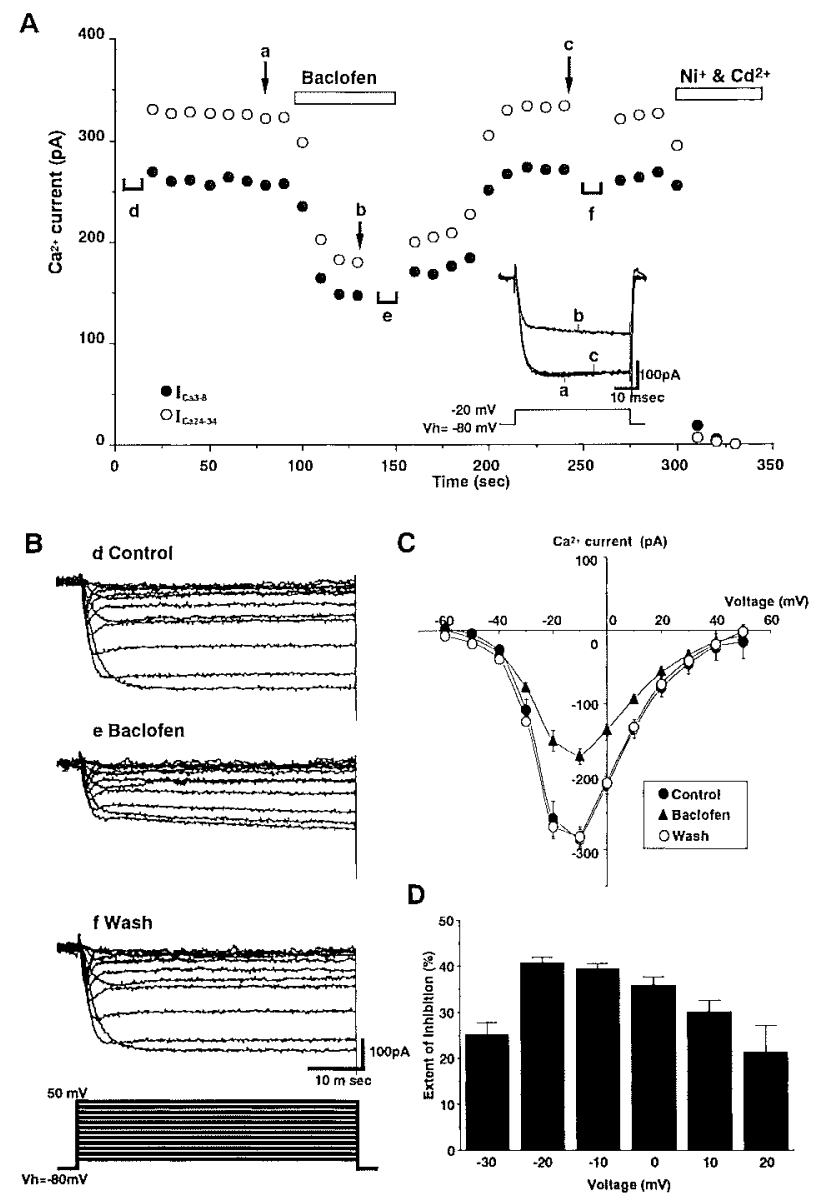

Fig. 1 Time course and current-voltage relations of $\mathrm{Ca}^{2+}$ currents in SON neurons isolated from young rats measured before, during and after application of baclofen $\left(10^{-5} \mathrm{M}\right)$. A. A representative time course of the baclofen $\left(10^{-5} \mathrm{M}\right)$-induced inhibition of $\mathrm{Ca}^{2+}$ currents. $\mathrm{Ca}^{2+}$ current traces obtained at times a-c are superimposed. B. Representative traces of leak-subtracted $\mathrm{Ca}^{2+}$ currents elicited by voltage steps to the command potentials between -60 to + $50 \mathrm{mV}(10 \mathrm{mV}$ intervals, $50 \mathrm{~ms})$, from a holding potential of $-80 \mathrm{mV}$, before, during and after application of baclofen $\left(10^{-5} \mathrm{M}\right)$. The traces were obtained at times d-f in Panel 'A'. C. The currentvoltage relation of $\mathrm{Ca}^{2+}$ currents before, during and after baclofen $\left(10^{-5} \mathrm{M}\right)$ application. The values represent the mean \pm SEM $(n=7)$. D. The voltage dependency of baclofen $\left(10^{-5} \mathrm{M}\right)$-induced inhibition of $\mathrm{Ca}^{2+}$ currents. The extent of inhibition was calculated from the current-voltage relation in Panel ' $\mathrm{C}$ '. 
A

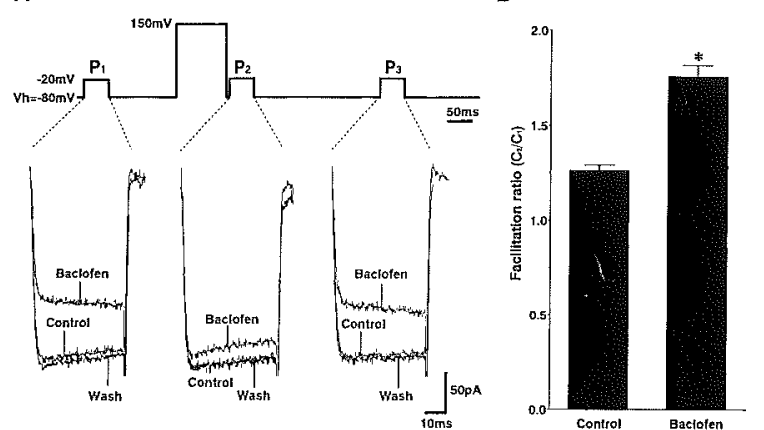

Fig. 2 Effects of depolarizing prepulse on baclofen $\left(10^{-5} \mathrm{M}\right)$-induced inhibition of voltagedependent $\mathrm{Ca}^{2+}$ currents (VDCC) in a SON neuron isolated from a young rat. A. Three consecutive $50 \mathrm{~ms}$ command pulses $\left(\mathrm{P}_{1}, \mathrm{P}_{2}\right.$ and $\left.\mathrm{P}_{3}\right)$ from $-80 \mathrm{mV}$ to $20 \mathrm{mV}$ were applied. The middle command $\left(P_{2}\right)$ was preceded by $5 \mathrm{~ms}$ by a prepulse to $150 \mathrm{mV}$ for $100 \mathrm{~ms}$. Three leak-subtracted current traces obtained before application of baclofen, during application of baclofen $\left(10^{-5} \mathrm{M}\right)$ and after wash are superimposed. B. Summary of the data obtained from 11 SON neurons. $\mathrm{Ca}^{2+}$ currents obtained from command pulses $\left(P_{1}\right.$ and $\left.P_{2}\right)$ were measured as $C_{1}$ and $C_{2}$, respective1y. $C_{1}$ and $C_{2}$ were integrated currents obtained from the average amplitude of $\mathrm{Ca}^{2+}$ currents between 3-8 msec after the statt of depolarizing voltage commands. The data are expressed as the ratio of integrated currents obtained after $\left(\mathrm{C}_{2}\right)$, to those obtained before $\left(\mathrm{C}_{1}\right)$ the depolarizing prepulse. The integrated currents were facilitated by the prepulse both before and in the presence of baclofen (control $\mathrm{C}_{2} / \mathrm{C}_{1}=$ $1.26 \pm 0.03$; baclofen $\left.C_{2} / C_{1}=1.76 \pm 0.06\right)$. The facilitation was significantly greater in the presence of baclofen ( $* P<0.05$, Student's paired $t$-test ).

(Fig. 2B).

\section{Effects of PTX on Baclofen-Induced Inhibition of VDCC in SON Neurons in Young Rats}

The effects of baclofen $\left(10^{-5} \mathrm{M}\right)$ on VDCC were examined $0-20,30-50$ and 60-80 mins after the rupture of the cell membrane using the pipette containing pre-activated PTX $(1 \mu \mathrm{g} / \mathrm{mL})$. In all of the 5 SON neurons examined, the baclofeninduced inhibition of VDCC was not affected by intracellular application of pre-activated PTX (Fig. 3). However, in each SON neuron, intracellularly applied TEA and 4-AP completely blocked the $\mathrm{K}^{+}$current within a few mins. This evidence confirmed access of pipette contents to the cell membrane.
Effects of PTX on 5-HT-induced Inhibition of Voltage-dependent $\mathrm{Ba}^{2+}$ Currents in Melanotrophs of Young Rats

Voltage-dependent $\mathrm{Ba}^{2+}$ currents were measured from 9 melanotrophs isolated from the neurointermediate lobe of pituitary glands from 4 young rats. $\mathrm{Ba}^{2+}$ was used as the charge carrier to measure voltage-dependent $\mathrm{Ca}^{2+}$ channels on these melanotrophs. 5-HT $\left(10^{-5} \mathrm{M}\right)$ inhibited the voltage-dependent $\mathrm{Ba}^{2+}$ currents in all melanotrophs recorded (Fig. 4A, B). The effects of 5-HT on voltage-dependent $\mathrm{Ba}^{2+}$ currents were examined 5, 20,30 and $40 \mathrm{~min}$ after the rupture of the cell membrane using pipettes containing preactivated PTX $(1 \mu \mathrm{g} / \mathrm{mL})$. 5-HT-induced inhibition of voltage-dependent $\mathrm{Ba}^{2+}$ currents was potently reduced by intracellular application of pre-activated PTX (Fig. 4B). 5-HT-induced inhibition of voltage-dependent $\mathrm{Ba}^{2+}$ currents was unaffected 5 and $20 \mathrm{~min}$ after rupture, but significantly reduced 30 and 40 min after the rapture of
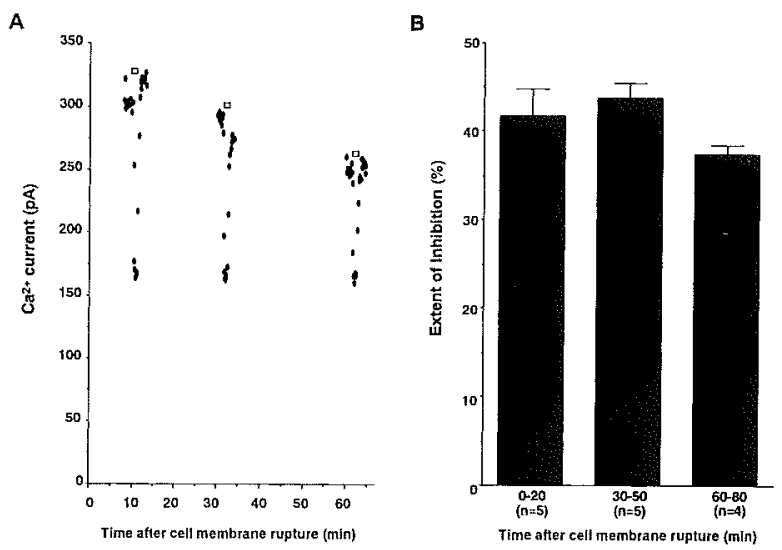

Fig. 3 Effects of intracellular application of preactivated pertussis toxin (PTX) on baclofen $\left(10^{-5}\right.$ $\mathrm{M})$-induced inhibition of voltage-dependent $\mathrm{Ca}^{2+}$ currents (VDCC) in SON neurons isolated from young rats. A. Baclofen-induced inhibition of VDCC was not affected $0-20,30-50$ and 60 min after the rapture of the cell membrane using the pipette containing pre-activated PTX $(1 \mu \mathrm{g} / \mathrm{mL}) . \mathrm{Ca}^{2+}$ currents were integrated currents obtained from the average amplitude of $\mathrm{Ca}^{2+}$ currents between 3-8 msec in a single neuron. Open bars indicate application of baclofen $\left(10^{-5} \mathrm{M}\right)$. B. Summary of the data for the inhibition of VDCC by baclofen $\left(10^{-5} \mathrm{M}\right)$ obtained from 4-5 cells. There were no significant changes in the extent of inhibition. The values represent the mean $\pm S E M$. 
A

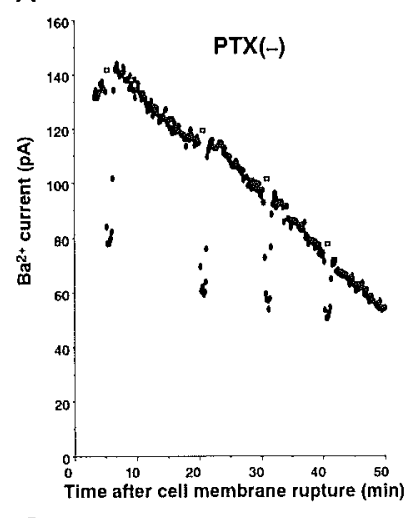

c

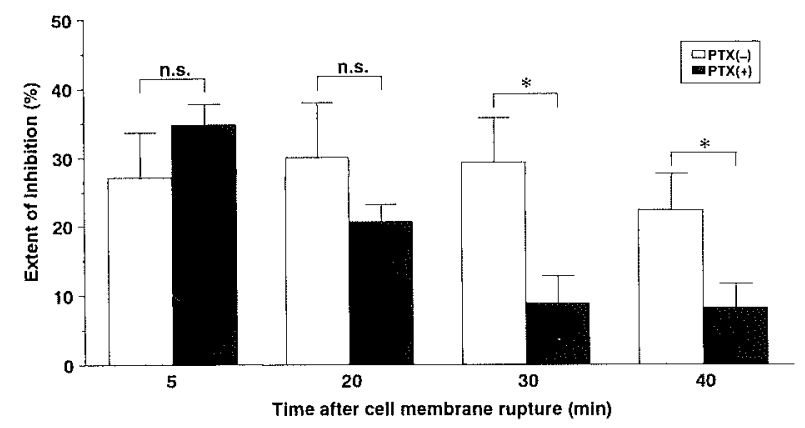

Fig. 4 Effects of serotonin (5-HT) $\left(10^{-5} \mathrm{M}\right)$ on voltage-dependent $\mathrm{Ba}^{2+}$ currents in a melanotrophs isolated from young rats with intracellular application of pre-activated pertussis toxin (PTX). Representative 5-HT $\left(10^{-5} \mathrm{M}\right)$-induced inhibition of $\mathrm{Ba}^{2+}$ currents in a rat melanotroph without (A) or with (B) intracellular application of pre-activated PTX. Open bars indicate application of $5-\mathrm{HT}\left(10^{-5} \mathrm{M}\right)$. C. Summary of the data for the inhibition of $\mathrm{Ba}^{2+}$ currents by 5 -HT $\left(10^{-5} \mathrm{M}\right)$ obtained from 4 cells without (open bars) and for 5 cells with (closed bars) PTX applied intracellularly. The values represent the mean $\pm S E M$. The extent of inhibition was significantly reduced in the presence of PTX at 30 and 40 mins after the rupture of cell membrane ( ${ }^{*} P<$ 0.05 , Student's unpaired $t$-test). n.s.; not significant.

the cell membrane using the pipette containing pre-activated PTX $(P<0.05)$ (Fig. $4 \mathrm{C})$.

\section{Expressions of $G$ Proteins $\alpha$-subunits Subtypes in the SON of Young Rats}

In situ hybridization histochemistry revealed that the expressions of the PTX-sensitive $\mathrm{G}$ proteins ( $\mathrm{Gi}$ and $\mathrm{Go}$ ) $\alpha$-subunit genes were not detected in the SON and the PVN of young rats (Fig. 5A, B, $\mathrm{D}, \mathrm{E})$. The expression of the PTX-insensitive (Gs) $\alpha$-subunit gene was, however, abundant in the
SON and PVN of young rats (Fig. 5C, F). In addition, the Gi, Go and Gs $\alpha$-subunits mRNAs were detected in many brain areas, including the hippocampus and the piriformcortex.

\section{DISCUSSION}

The present study demonstrated that baclofen inhibited VDCC in SON magnocellular neurons isolated from young rats via a PTX-insensitive $G$ protein. In situ hybridization histochemistry showed that the PTX-sensitive G proteins ( $\mathrm{Gi}$ and Go) $\alpha$-subunits were not expressed in the SON of young rats.

Baclofen $\left(10^{-5} \mathrm{M}\right)$ potently inhibited VDCC in SON neurons isolated from young rast. This result was similar to that obtained from infant rats (8). This inhibition was reversed by a large depolarizing prepulse suggesting that this baclofen-induced inhibition of the VDCC occurred mainly through the "membrane-delimited" pathway with a direct interaction between $\mathrm{G} \beta \gamma$ subunits and the $\operatorname{VDCC}(10,12)$. We also observ-

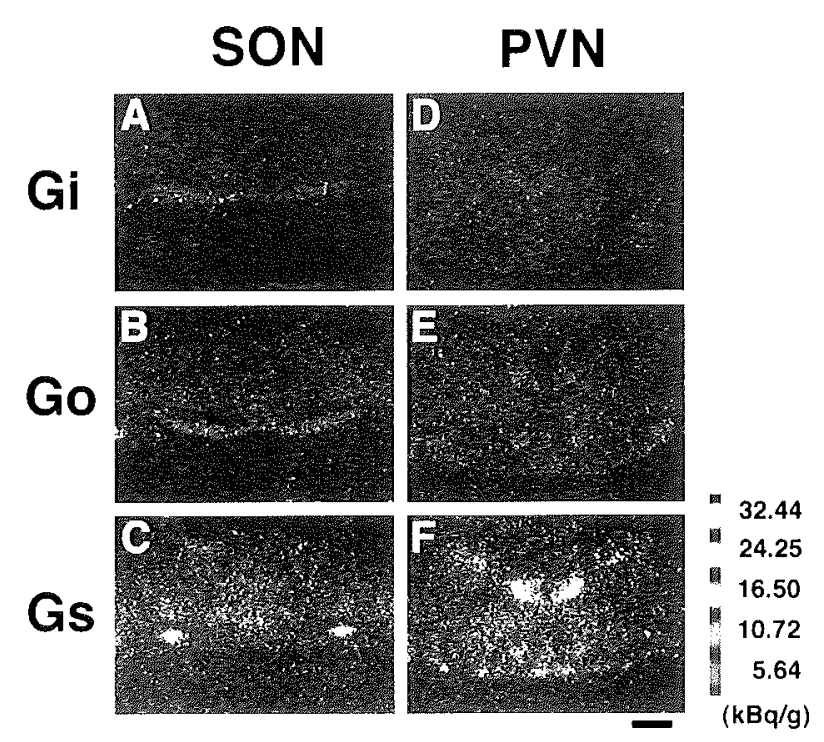

Fig. 5 Expressions of Gi, Go and Gs $\alpha$-subunits' genes in the SON and the PVN of young rat. A, D. The expression of $\mathrm{Gi} \alpha$-subunit gene was not detected in the SON and the PVN. B, E. The expression of Go $\alpha$-subunits gene was not detected in the SON and the PVN. C, F. The expression of Gs $\alpha$-subunit gene was abundant in the SON and the PVN. A to $C$ are serial sections, including the SON. D to $F$ are also serial sections, including the PVN. The scale bar indicates $1 \mathrm{~mm}$. The optical density of autoradiographs was compared with simultaneously exposed $\left[{ }^{14} \mathrm{C}\right]$ micro-scale samples. 
ed in this study a facilitation of VDCC by a depolarizing prepulse (to $150 \mathrm{mV}$ for $100 \mathrm{~ms}$ ). This observation indicates that VDCCs in these isolated SON neurons are tonically inhibited in a voltage-dependent manner.

In the present study we showed that PTX has no effects on the baclofen-induced inhibition of VDCC in SON neurons isolated from young rats. Harayama et al. demonstrated that baclofen inhibited VDCC in SON neurons isolated from infant rats (1-3 weeks) and this inhibitory action on VDCC were mediated via PTX-sensitive $G$ proteins (9). A possible explanation for the differences between these studies are the different method used to apply PTX to the neuron and the different ages of rats used.

In the study of Harayama et al., the SON neurons were incubated in a PTX $(1 \mu \mathrm{g} / \mathrm{mL})$ containing solution (9). In the present study PTX was administered intracellularly by using a patchclamp pipette solution containing pre-activated PTX $(1 \mu \mathrm{g} / \mathrm{mL})$. To confirm the effectiveness of the method used here, melanotrophs isolated from young rats were studied. Although a "run-down" of $\mathrm{Ba}^{2+}$ currents was observed after the rupture of the melanotroph cell membrane, application of 5-HT produced repeated inhibition of the voltagedependent $\mathrm{Ba}^{2+}$ currents. We clearly showed that the 5-HT-induced inhibition of these melanotroph voltage-dependent $\mathrm{Ba}^{2+}$ currents was significantly reduced by intracellular application of pre-activated PTX $(1 \mu \mathrm{g} / \mathrm{mL})$. This result is in agreement with a previous study in rat isolated melanotrophs which demonstrated that extracellularly applied PTX reduces 5-HTinduced inhibition of voltage-dependent $\mathrm{Ca}^{2+}$ channels (5). The difference in the method of applying PTX to a SON neuron seems not to be the reason why baclofen-induced inhibition of VDCC was not affected by PTX.

ADP-ribosylation by PTX in the rat CNS increased for up to 1 week after birth, and then decreased (3). The contents of $\mathrm{G}$ proteins and their mRNAs changes in the developing rat brain $(3,8)$. Thus, there is a possibility that the PTXsensitivity, and the contents of PTX-sensitive G proteins in the SON may change during postnatal development. One explanation why the baclofeninduced inhibition of VDCC was not affected by PTX is that PTX-sensitive G proteins may not be functional in the SON magnocellular neurons in our preparation. In situ hybridization histochemistry revealed that the expressions of the
PTX-sensitive G proteins (Gi and Go) $\alpha$-subunit genes were not detected in the SON of the young rats used in the present study. In contrast, Gs $\alpha$-subunit mRNA was abundant in the SON of these young rats. As the sensitivities of the probes for $\mathrm{Gi}$ and Go proteins mRNAs may be too low to detect small amounts of mRNA levels, one can only tentatively conclude that there is no Gi/o proteins $\alpha$-subunits in the young rat SON. However, these results do raise the possibility that PTX-insensitive $G$ proteins may mediate the baclofen induced-inhibition of VDCC in the young rat SON.

Vasoactive intestinal polypeptide (VIP)induced inhibition of VDCC in neurons isolated from rat superior cervical ganglia (SCG) is mediated by PTX-insensitive Gs $\alpha$-subunits (33). Adrenaline-induced inhibition of VDCC in the Xenopus oocyte expression system was also mediated by PTX-insensitive Gs $\alpha$-subunits (6). Recent studies demonstrated that $\mathrm{Gz} \alpha$-subunits also mediate receptor-induced inhibition of VDCCs $(6,14)$. These PTX-insensitive G proteins may be candidates which mediate the baclofeninduced inhibition of VDCC in SON magnocellular neurons isolated from young rats. These possibilities should be clarified by further study.

In conclusion, the inhibition of VDCC due to activation of $\mathrm{GABA}_{\mathrm{B}}$ receptors in SON magnocellular neurons isolated from young rats seems to be mediated by PTX-insensitive G proteins.

Acknowledgments. This study was supported in part by No 10470019 and 10218210 for H. Y. from the Ministry of Education, Science, Sports and Culture, Japan, the research grant from the Ministry of Health and Welfare and the Salt Science Research Foundation. We thank Dr. Andrew Moorhouse (School of Physiology and Pharmacology, UNSW) for helpful comments on this manuscript.

\section{REFERENCES}

1. Bormann J. (1988) Electrophysiology of GABA and $\mathrm{GABA}_{\mathrm{B}}$ receptor subtypes. Trends Neurosci. 11, 112116.

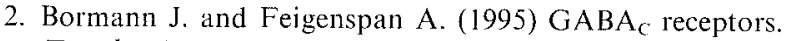
Trends Nelirosci. 18, 515-519.

3. Chang K. J., Pugh W., Blanchard S. G., McDermed J. and Tam J. P. (1988). Antibody specific to the $\alpha$ subunit of the guanine nucleotide-binding regulatory protein Go: developmental appearance and immunocytochemical localization in brain. Proc. Natl. Acad. Sci. USA 85, 
4929-4933.

4. Chen G. and van den Pol AN.(1998). Presynaptic GABA autoreceptor modulation of $\mathrm{P} / \mathrm{Q}$-type calcium channels and GABA release in rat suprachiasmatic nucleus neurons. J. Neurosci. 18, 1913-22.

5. Ciranna L., Feltz P. and Schlichter R. (1996). Selective inhibition of high voltage-activated L-type and Qtype $\mathrm{Ca}^{2+}$ currents by serotonin in rat melanotrophs. $J$. Physiol. 490, 595-609.

6. Furukawa T., Miura R., Mori Y., Strobeck M., Suzuki K., Ogihara Y., Asano T., Morishita R., Hasii M., Higashida H., Yoshii M. and Nukada T. (1998). Differential interaction of $\mathrm{C}$ terminus and the cytoplasmic I-II Loop of neuronal $\mathrm{Ca}^{2+}$ channels with G-protein $\alpha$ and $\beta \gamma$ subunits. J. Biol. Chem. 273, 17595-17603.

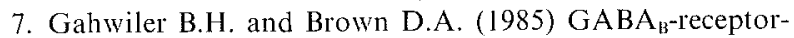
activated $\mathrm{K}^{+}$current in voltage-clamped $\mathrm{CA} 3$ pyramidal cells in hippocampal cultures. Proc. Natl. Acad. Sci. USA 82, $1558-1562$.

8. Gariby J.L.R., Kozasa T., Itho H., Tsukamoto T., Matsuoka M. and Kaziro Y.(1991) Analysis by mRNA levels of expression of six $\mathrm{G}$ protein $\alpha$-subunit genes in mammalian cells and tissues. Biochem. Biophys. Acta. 1094, 193-199.

9. Harayama N., Shibuya I., Tanaka K., Kabashima N., Ueta $\mathrm{Y}$. and Yamashita H. (1998) Inhibition of $\mathrm{N}$ - and P/ Q-type calcium channels by postsynaptic $\mathrm{GABA}_{\mathrm{B}}$ receptor activation in rat supraoptic neurones. J. Physiol . 509, 37I383.

10. Herlitze S., Garcia D. E., Mackie K., Hille B., Scheuer T. and Catterall W. A. (1996). Modulation of $\mathrm{Ca}^{2+}$ channels by G-protein $\beta \gamma$ subunits. Nature 380, 258-262.

11. Ibrahim N., Shibuya I., Kabashima N., Setiadji V. S., Ueta Y. and Yamashita H. (1998) GABA $\mathrm{B}$ receptor-mediated inhibition of spontaneous action potential discharge in rat supraoptic neurons in vitro. Brain Res. 813, 88-96.

12. Ikeda S. R. (1996). Voltage-dependent modulation of $N$-type calcium channels by G-protein $\beta \gamma$ subunits. Nature 380, 255-258

13. Inoue Y., Shibuya I, Kabashima N., Noguchi J., Harayama N. Ueta Y., Sata T., Shigematsu A. and Yamashita H. (1999) The mechanism of inhibitory actions of propofol on rat supraoptic neurons. Anesthesiology 91, $167-178$.

14. Jeong S. W. and Ikeda S. R. (1998). G protein $\alpha$ subunit $\mathrm{G} \alpha_{z}$ couples neurotransmitter receptors to ion channels in sympathetic neurons. Neuron 21, 1201-1212.

15. Jeong S. W. and Ikeda S. R. (1999). Sequestration of G-protein $\beta \gamma$ subunits by different G-protein alpha subunits blocks voltage-dependent modulation of $\mathrm{Ca}^{2+}$ channels in rat sympathetic neurons. $J$. Neurosci.19, 47554761.

16. Kabashima N., Shibuya I., Ibrahim N., Ueta Y. and Yamashita H.(1997) Inhibition of spontaneous EPSCs and IPSCs by presynaptic $\mathrm{GABA}_{\mathrm{B}}$ receptors on rat supraoptic magnocellular neurons. J. Physiol. 504, 113-126.

17. Kakehata S., Nakagawa T., Takasaka T. and Akaike N. (1993). Cellular mechanism of acetylcholine-induced response in dissociated outer hair cells of guinea-pig cochlea. J. Physiol, 463, 227-244.
18. Kammermeier P. J. and Ikeda S. R. (1999). Expression of RGS2 alters the coupling of metabotropic glutamate receptor la to $\mathrm{M}$-type $\mathrm{K}^{+}$and $\mathrm{N}$-type $\mathrm{Ca}^{2+}$ channels. Neuron 22, 819-829.

19. Kaupmann K., Huggel K., Heid J., Flor P.J., Bischoff S., Mickel S.J., MacMaster G., Angst C., Bittiger H., Froestl W. and Bettler B.(1997) Expression cloning of $\mathrm{GABA}_{B}$ receptors uncovers similarity to metabotropic glutamate receptors. Nature 386, 239-246.

20. Mason W.T., Poulain D. and Cobbett P. (1987) $\gamma$ Aminobutyric acid as an inhibitory neurotransmitter in the rat supraoptic nucleus: intracellular recordings in the hypothalamic slice. Neurosci. Lett. 73, 259-265.

21. Mody I., De Koninck Y., Otis T.S. and Soltesz I. (1994) Bridging the cleft at GABA synapses in the brain. Trends Neurosci. 17, 517-525.

22. Mouginot D., Kombian S. B. and Pittman Q.J.(1998) Activation of presynaptic $\mathrm{GABA}_{\mathrm{B}}$ receptors inhibits evoked IPSCs in rat magnocellular neurons in vitro. $J$. Neurophysiol. 79, 1508-1517.

23. Newberry N.R. and Nicoll R.A. (1984) Direct hyperpolarizing action of baclofen on hippocampal pyramidal cells. Nature 308, 450-452.

24. Nicoll R.A., Malenka R.C. and Kauer J.A. (1990) Functional comparison of neurotransmitter receptor subtypes in mammalian central nervous system. Physiol. Rev. 70, 513565.

25. Nissen R. and Renaud L.P. (1994) GABA receptor mediation of median preoptic nucleus-evoked inhibition of supraoptic neurosecretory neurones in rat. $J$. Physiol. 479, 207-216.

26. Oliet S.H.R. and Bourque C.W. (1992) Properties of supraoptic magnocellular neurones isolated from the adult rat. J. Physiol. 455, 291-306.

27. Paxinos G.and Watson C. (1986). The Rat Brain in Stereotaxic Coordinates, Academic Press, Sydney.

28. Randle J.C.R. and Renaud L.P. (1987) Action of $\gamma$ aminobutyric acid on rat supraoptic nucleus neurosecretory neurones in vitro. J. Physiol. 87, 629-647.

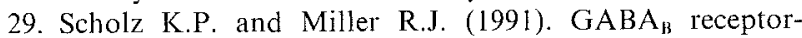
mediated inhibition of $\mathrm{Ca}^{2+}$ currents and synaptic transmission in cultured rat hippocampal neurones. J. Physiol. 444, 669-686.

30. Sieghart W. (1992) $\mathrm{GABA}_{A}$ receptors: ligand-gated $\mathrm{Cl}^{-}$ion channels modulated by multiple drug-binding site. Trends Pharmacol. Sci. 13, 446-450.

31. Thalmann R. H. (1988) Evidence that guanosine triphosphate(GTP)-binding proteins control a synaptic response in brain: Effect of pertussis toxin and GTP $\gamma \mathrm{S}$ on the late inhibitory postsynaptic potential of hippocampal CA3 neurons. J. Neurosci. 8, 4589-4602.

32. Wuarin J.P. and Dudek F.E. (1993) Patch-clamp analysis of spontaneous synaptic currents in supraoptic neuroendocrine cells of the rat hypothalamus. J. Neurosci. 13, 23232331

33. Zhu Y. and Ikeda S.R. (1994). VIP inhibits N-type $\mathrm{Ca}^{2+}$ channels of sympathetic neurons via a pertussis toxininsensitive but cholera toxin-sensitive pathway. Neuron 13, $657-669$. 